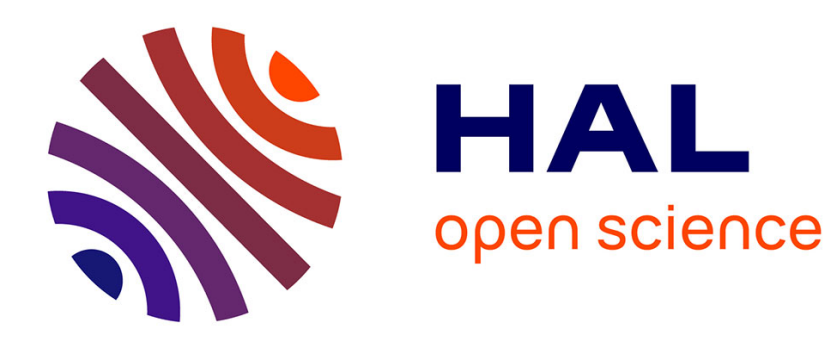

\title{
Optimizing precision of rotating compensator ellipsometry
}

L. Broch, L. Johann

\section{To cite this version:}

L. Broch, L. Johann. Optimizing precision of rotating compensator ellipsometry. ICSE-4 - 4th International Conference on Spectroscopic Ellipsometry, 2007, Stockholm, Sweden. hal-02900958

\section{HAL Id: hal-02900958 \\ https://hal.univ-lorraine.fr/hal-02900958}

Submitted on 16 Jul 2020

HAL is a multi-disciplinary open access archive for the deposit and dissemination of scientific research documents, whether they are published or not. The documents may come from teaching and research institutions in France or abroad, or from public or private research centers.
L'archive ouverte pluridisciplinaire HAL, est destinée au dépôt et à la diffusion de documents scientifiques de niveau recherche, publiés ou non, émanant des établissements d'enseignement et de recherche français ou étrangers, des laboratoires publics ou privés. 


\title{
Optimizing precision of rotating compensator ellipsometry
}

\author{
L. Broch and L. Johann \\ Laboratoire de Physique des Milieux Denses, Université Paul Verlaine-Metz, \\ 1 Bd Arago, 57078 Metz cedex 3, France \\ ए broch@univ-metz.fr
}

Many authors proposed algorithms and methods for the calibration of the elements and for the reduction of the errors in measurements in order to increase the performance of ellipsometers [1-3]. In particular, an optimized tracking method which reduces random errors has been applied on rotating polarizer ellipsometry [4]. The aim of this work is to propose a method especially adapted to the RCE ellipsometers when measurements with a high degree of accuracy are required.

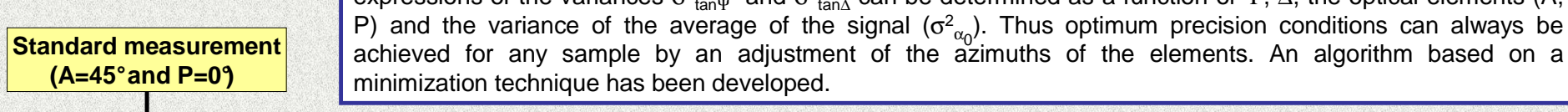

In the PCSA configuration (Polarizer, Compensator, Sample, Analyzer), the ellipsometric parameters of the sample, $\tan \Psi$ and $\tan \Delta$ are deduced from the Fourier coefficients of the detected light. The computed expressions of the variances $\sigma_{\tan \Psi}^{2}$ and $\sigma_{\tan \Delta}^{2}$ can be determined as a function of $\Psi, \Delta$, the optical elements (A, $\left(\mathrm{A}=45^{\circ}\right.$ and $\mathrm{P}=\mathbf{0}$ )

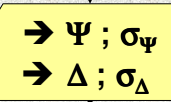

Optimization for Tan $\Delta$

Tracking analyzer
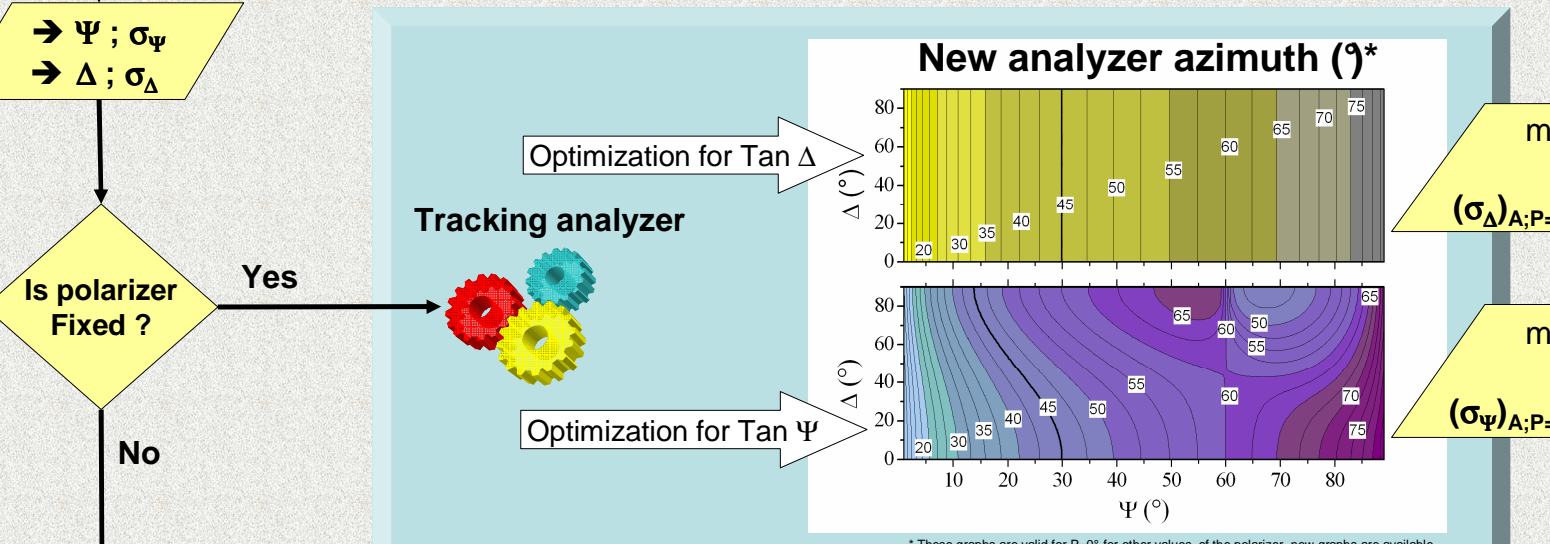

$$
\left(\sigma_{\Delta}\right)_{\mathrm{A} ; \mathrm{P}=0^{\circ}}<\left(\sigma_{\Delta}\right)_{\mathrm{A}=45^{\circ} ; \mathrm{P}=0^{\circ}}
$$

$$
\rightarrow \Delta ; \sigma_{\Delta}
$$

- These graphs are valid for $\mathrm{P}=0^{0}$, for other values of the polarizer, new graphs are available.

Tracking both analyzer and polarizer
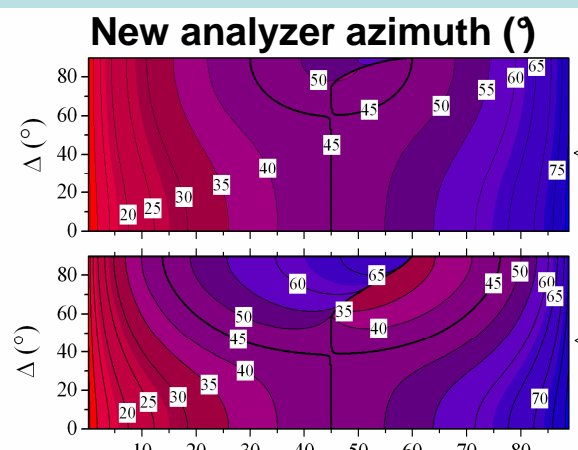

$\Psi\left({ }^{\circ}\right)$
Optimization for Tan $\Delta$

Optimization for Tan $\Psi$

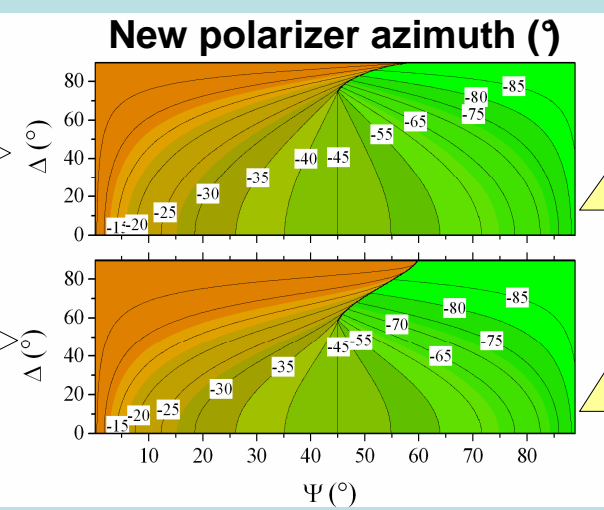

measurement

$\rightarrow \Delta ; \sigma_{\Delta}$

$\left(\sigma_{\Delta}\right)_{\mathrm{A} ; \mathrm{P}}<\left(\sigma_{\Delta}\right)_{\mathrm{A}=45 ; \mathrm{P}=0^{\circ}}$

mis

measurement

$\rightarrow \Psi ; \sigma_{\Psi}$

$\left(\sigma_{\Psi}\right)_{\mathrm{A} ; \mathrm{P}}<\left(\sigma_{\Psi}\right)_{\mathrm{A}=45 ; \mathrm{P}=0^{\circ}}$
$\sigma_{\Psi}$ and $\sigma_{\Delta}$ with tracking both analyzer and polarizer compared to $\sigma_{\Psi}$ and $\sigma_{\Delta}$ obtained with $A=45^{\circ}$ and $\mathrm{P}=0^{\circ}$.
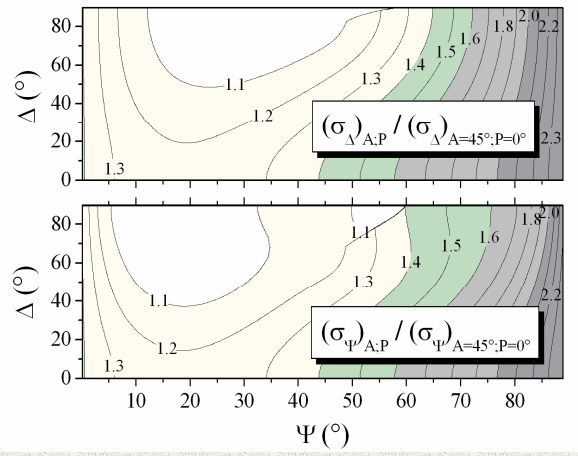

The positions of the optical elements determined by this method increase the signalto-noise ratio. Consequently, the random errors decrease and the precision of the ellipsometric angles of the sample increase. The measurements validate and confirm the improvement of this method. The standard deviation of the $\Psi$ and $\Delta$ angles measured by the tracking both analyzer and polarizer is always lower than the standard deviation obtained by the tracking analyzer alone. We

\begin{tabular}{|c|c|c|c|c|c|}
\hline & \multicolumn{5}{|c|}{$\begin{array}{l}\text { Measurements for a } 125 \mathrm{~nm}-\mathrm{SiO}_{2} / \mathrm{SI} \text { sample } \\
\left(\lambda=633 \mathrm{~nm} \text { and } 70^{\circ} \text { of incidence }\right)\end{array}$} \\
\hline & \multirow{2}{*}{$\begin{array}{l}\text { Standard } \\
\mathrm{A}=45^{\circ}, \mathrm{P}=0^{\circ}\end{array}$} & \multicolumn{2}{|c|}{ Tracking analyzer } & \multicolumn{2}{|c|}{ Tracking both analyzer and polarizer } \\
\hline & & $\mathrm{A}=47.38^{\circ}, \mathrm{P}=0^{\circ}$ & $\mathrm{A}=62.14^{\circ}, \mathrm{P}=0^{\circ}$ & $\mathrm{A}=47.46^{\circ}, \mathrm{P}=-84.85^{\circ}$ & $\mathrm{A}=35.0^{\circ}, \mathrm{P}=-87.83^{\circ}$ \\
\hline$\Psi\left({ }^{\circ}\right)$ & 63.982 & 63.967 & & & 63.972 \\
\hline$\sigma_{\mathbb{V}}$ & 0.012 & 0.011 & & & 0.006 \\
\hline$\Delta\left(^{\circ}\right)$ & 84.430 & & 84.448 & 84.435 & \\
\hline$\sigma_{\Delta}$ & 0.033 & & 0.030 & 0.022 & \\
\hline \multicolumn{6}{|c|}{$\begin{array}{l}\text { References : } \\
\text { [1] R. Kleim, L. Kuntzler and A. El Ghemmaz, J. Opt. Soc. Am A 9, } 11 \text { (1994) } \\
\text { [2] D. E. Aspnes, J. Opt. Soc. Am A 3, 21 (2004) } \\
\text { [3] R. W. Collins, in Handbook of Ellipsometry, edited by H. G. Tompkins and E. A. Irene William } \\
\text { Andrew, New York/Springer-Verlag, Berlin, 2005, Chap. 7. pp. 481-556. } \\
\text { [4] A. En Naciri, L. Broch, L. Johann and R. Kleim, Thin Solid Films 406, 103-112 (2002) }\end{array}$} \\
\hline
\end{tabular}
note that better results are obtained with samples where $\Psi$ is $\leq 10^{\circ}$ or $\geq 50^{\circ}$. 